\title{
Psoriatic lesion regression - thermographic evaluation
}

\author{
Anna Zalewska ${ }^{1}$, Grzegorz Gralewicz ${ }^{2}$, Grzegorz Owczarek ${ }^{2}$, Bogusław Więcek ${ }^{3}$ \\ ${ }^{1}$ Department of Psychodermatology, Chair of Dermatology and Venereology, Medical University of Lodz, Poland \\ ${ }^{2}$ Central Institute for Labour Protection - National Research Institute, Warsaw, Poland \\ ${ }^{3}$ Institute of Electronics, Computer Thermography Group, Technical University of Lodz, Poland
}

\begin{abstract}
Psoriasis vulgaris is a chronic inflammatory skin disease characterized by hyperkeratosis, dermal inflammatory infiltrate and increased angiogenesis. The aim of the present study was to assess usefulness of thermography in psoriatic lesion regression. Ten in-patients with psoriasis vulgaris were included in the study. ThermaCam INFRAMETRICS 290E thermocamera with temperature resolution of 0.1 oC was employed. Both visual and thermal images, derived from four body regions i.e. chest, back, upper and lower limbs of lesional and lesion-free areas were recorded and analyzed. A significant decrease in temperature measurement was observed along with efficient treatment both over skin lesions and lesion-free areas. There was also a significant decrease in erythema severity in all the examined areas. A negative correlation was noted between temperature and desquamation on the chest and between temperature and infiltration on the back. It is conceivable to speculate that temperature measurement could serve as a marker of disease remission. What is more, lesion-free skin in psoriatic patients seems to be somewhat involved in the pathological process in psoriasis suggesting that it is „prepared” for lesion progression.
\end{abstract}

Key words- thermography, thermal imaging, dermatology, skin, psoriasis.

\section{INTRODUCTION}

Psoriasis is a chronic, recurrent skin disease with strong genetic and environmental components, effecting 1 to $2 \%$ of human population worldwide [1-3]. Histopathological examination reveals characteristic features such as hyperparakeratosis, lack of granular layer in the epidermis, dermal inflammatory infiltrate together with vascular changes such as new blood vessel formation and widening of their lumen $[4,5]$. All of the above abnormalities are able to influence temperature measurement. Literature data point out at microvascular abnormalities, reporting up to 10 times increased blood flow through psoriatic lesions compared to the normal healthy skin, and inflammation as factors playing an important role in psoriatic plaques development [5-11]. It was also shown that structural expansion and increased tortuosity of the dermal capillary loops occurs fairly early in the development of skin lesions, even before epidermal hyperplasia and inflammatory infiltrate can be viewed on histopathology [11-15].

Thermograpic methods are more and more frequently used in everyday medical procedures and among others, also in dermatology. Literature data point out at quite extensive use of thermal imaging methods in diseases of inflammatory or vascular background but also in many other conditions including scleroderma, morphea, basal cell carcinoma, chilblains, port wein stains, melanocytic naevi, melanoma, Raynaud's phenomenon, evaluation of patch and prick tests and regression of skin lesions [16-22].

The aim of this study was to evaluate usefulness of thermal imaging methods in psoriatic lesion regression assessment.

\section{METHODOLOGY}

Ten male in-patients with chronic plaque type psoriasis vulgaris were included in the study. Most representative psoriatic lesions located on the trunk, back and upper limbs together with lesion-free areas designated at least $5 \mathrm{~cm}$ from the edge of an examined psoriatic plaque were selected for evaluation. The patients did not take any systemic treatment in the last 2 weeks and local ones, except for emollients for the last week. The disease duration ranged from 5 to 25 years. Based on the past medical history the selected patients did not suffer from psoriatic arthritis and they presented stable lesions (already developed at least 8 weeks before, without signs of visible progression). The lesions were divided according to their location into 4 groups: situated on the upper limbs, chest, back and lower limbs. On the day of thermographic procedure all the patients were not applying any local treatment to the skin in order to avoid its irritation and additional stimulation of blood flow. They were also asked to refrain from smoking and drinking coffee and instructed not to eat anything for 3 hours before the thermographic examination. Just before the procedure, they were prepared in a special room with controlled temperature for 30 minutes $(20 \circ \mathrm{C})$. Based on the past medical history, after a thermographic examination, all the patients were on classical antipsoriatic regiments i.e. either Ingram's method (local anthralin plus UVB) or Goeckerman's method (local tar plus UVB).

Thermocamera ThermaCam INFRAMETRICS 290E was used in the study. Temperature resolution was $0.1 \mathrm{oC}$, mean, standard deviation, standard error of the mean and variability were calculated. A $p$ value equal 0.05 or less was considered statistically significant. All thermal images were captured and processed through high-speed Peripheral Component Interconnect (PCI) interface. This interface links up to 4 CCD cameras and 1 thermal camera with the powerful computer, and offers the high performance of 32-bit data transfer an optional 
burst mode that provides accelerated throughput of data across the bus of $132 \mathrm{MB} / \mathrm{s}$. ThermalStudio software was used. Both thermal and visual images of all the patients were recorded and analyzed [23].

Each plaque was estimated for erythema, desquamation and infiltration (each ranged from 0 to 4 ) before treatment (I), on 7th day of treatment (II) and on 14th day of treatment (III).

\section{RESULTS}

A significant decrease in temperature measurement was observed along with efficient treatment both over psoriatic plaques and lesion-free skin. There was also a significantly increased temperature over psoriatic plaques in comparison to lesion-free skin. Detailed data is presented in Table 1.

Along with successful treatment, there was a significant decrease in eryhtema severity in all the examined areas together with infiltration improvement on the chest, upper and lower limbs. Detailed data is presented in Table 2.

There was a negative correlation between temperature measurement and desquamation on the chest $(r=-$ $0.63, p=0.05)$. Also a negative correlation between temperature and infiltration was noted on the back $(r=-0.72$, $\mathrm{p}=0.02)$ and lower limbs $(\mathrm{r}=-0.64, \mathrm{p}=0.05)$.

An example of psoriatic lesions located over the back and their regression is presented in fig. 1.

Table 1. Temperature measurement over psoriatic plaques and lesion-free skin

\begin{tabular}{|c|c|c|c|c|c|c|c|}
\hline \multirow{2}{*}{\multicolumn{2}{|c|}{ Examined area }} & \multirow{3}{*}{$\begin{array}{l}\text { Statisti-cal } \\
\text { parameter } \\
\text { [oC] or [\%] } \\
\mathbf{X}\end{array}$} & \multicolumn{3}{|c|}{ Temperature $[\mathrm{oC}]$} & \multirow{2}{*}{\multicolumn{2}{|c|}{$\begin{array}{l}\text { P value }<0.05 \\
\text { or lower* }\end{array}$}} \\
\hline & & & \multirow{2}{*}{$\begin{array}{l}\text { Before } \\
\text { treatment - } \\
\text { 1st week (a) } \\
\mathbf{3 4 . 1}\end{array}$} & \multirow{2}{*}{\begin{tabular}{|l|}
$\begin{array}{l}\text { 7th day of } \\
\text { treatment - } \\
\text { 2nd week (b) }\end{array}$ \\
33.3 \\
\end{tabular}} & $\begin{array}{l}\text { 14th day of } \\
\text { treatment - } \\
\text { 3rd week } \\
\text { (c) }\end{array}$ & & \\
\hline \multirow{8}{*}{ Trunk } & \multirow{4}{*}{$\begin{array}{l}\text { Skin } \\
\text { lesions (1) }\end{array}$} & & & & 32.1 & \multirow{4}{*}{$\begin{array}{l}\text { (a)-(b) }<0.05^{*} \\
\text { (a)-(c) }<0.001^{*} \\
\text { (b)-(c) } p<0.01^{*}\end{array}$} & \multirow{8}{*}{$\begin{array}{l}(1 a)-(2 a) \\
p<0 ., 05^{\star} ; \\
(1 b)-(2 b) \\
p<0.01^{*} ; \\
(1 c)-(2 c) \\
p>0.05\end{array}$} \\
\hline & & SD & 0.8 & 0.7 & 1.0 & & \\
\hline & & SEM & 0.2 & 0.2 & 0.3 & & \\
\hline & & $\mathrm{V}[\%]$ & 2.3 & 2.2 & 3.0 & & \\
\hline & \multirow{4}{*}{$\begin{array}{l}\text { Lesion-free } \\
\text { skin (2) }\end{array}$} & $X$ & 33.0 & 32.3 & 31.3 & \multirow{4}{*}{$\begin{array}{l}\text { (a)-(b) } p>0.05 \\
\text { (a)-(c) } p<0.001^{*} \\
\text { (b)-(c) } p<0.05^{*}\end{array}$} & \\
\hline & & SD & 0.9 & 0.7 & 1.0 & & \\
\hline & & SEM & 0.3 & 0.2 & 0.3 & & \\
\hline & & $\mathrm{V}[\%]$ & 2.6 & 2.2 & 3.3 & & \\
\hline \multirow[t]{8}{*}{ Back } & \multirow{4}{*}{$\begin{array}{l}\text { Skin } \\
\text { lesions (1) }\end{array}$} & $\mathrm{X}$ & 33.6 & 32.6 & 31.8 & \multirow{4}{*}{$\begin{array}{l}\text { (a)-(b) } p>0.05 \\
\text { (a)-(c) } p<0.01^{*} \\
\text { (b)-(c) } p<0.05^{*}\end{array}$} & \multirow{8}{*}{$\begin{array}{l}(1 a)-(2 a) \\
p<0.05^{\star} \\
(1 b)-(2 b) \\
p<0.05^{\star} \\
(1 c)-(2 c) \\
p<0.01^{*}\end{array}$} \\
\hline & & SD & 1.2 & 1.0 & 0.9 & & \\
\hline & & SEM & 0.4 & 0.3 & 0.3 & & \\
\hline & & $\mathrm{V}[\%]$ & 3.4 & 3.0 & 2.9 & & \\
\hline & \multirow{4}{*}{$\begin{array}{l}\text { Lesion-free } \\
\text { skin (2) }\end{array}$} & $\mathrm{X}$ & 32.3 & 31.3 & 30.4 & \multirow{4}{*}{$\begin{array}{l}\text { (a)-(b) } p>0.05 \\
\text { (a)-(c) } p<0.01^{*} \\
\text { (b)-(c) } p>0.05\end{array}$} & \\
\hline & & SD & 1.4 & 1.1 & 1.0 & & \\
\hline & & SEM & 0.4 & 0.4 & 0.3 & & \\
\hline & & $\mathrm{V}[\%]$ & 4.3 & 3.6 & 3.2 & & \\
\hline \multirow{8}{*}{$\begin{array}{l}\text { Upper } \\
\text { limbs }\end{array}$} & \multirow{4}{*}{$\begin{array}{l}\text { Skin } \\
\text { lesions (1) }\end{array}$} & $\mathrm{X}$ & 34.0 & 33.1 & 32.0 & \multirow{4}{*}{$\begin{array}{l}\text { (a)-(b) } p<0.05^{*} \\
\text { (a)-(c) } p<0.001^{*} \\
\text { (b)-(c) } p<0.001^{*}\end{array}$} & \multirow{8}{*}{$\begin{array}{l}(1 a)-(2 a) \\
p<0.001^{*} \\
(1 b)-(2 b) \\
p<0.001^{*} \\
(1 c)-(2 c) \\
p<0.001^{*}\end{array}$} \\
\hline & & SD & 0.8 & 0.6 & 0.7 & & \\
\hline & & SEM & 0.2 & 0.2 & 0.2 & & \\
\hline & & $\mathrm{V}[\%]$ & 2.2 & 2.0 & 2.0 & & \\
\hline & \multirow{4}{*}{$\begin{array}{l}\text { Lesion-free } \\
\text { skin (2) }\end{array}$} & $\mathbf{X}$ & 32.1 & 31.3 & 30.4 & \multirow{4}{*}{$\begin{array}{l}\text { (a)-(b) } p>0.05 \\
\text { (a)-(c) } p<0.001^{*} \\
\text { (b)-(c) } p<0.05^{*}\end{array}$} & \\
\hline & & SD & 1.1 & 0.8 & 0.7 & & \\
\hline & & SEM & 0.3 & 0.3 & 0.2 & & \\
\hline & & $\mathrm{V}[\%]$ & 3.3 & 2.7 & 2.2 & & \\
\hline \multirow{8}{*}{$\begin{array}{l}\text { Lower } \\
\text { limbs }\end{array}$} & \multirow{4}{*}{$\begin{array}{l}\text { Skin } \\
\text { lesions (1) }\end{array}$} & $\mathbf{X}$ & 33.4 & 32.3 & 31.3 & \multirow{4}{*}{$\begin{array}{l}\text { (a)-(b) } p<0.05^{\star} \\
\text { (a)-(c) } p<0.001^{*} \\
\text { (b)-(c) } p>0.05\end{array}$} & \\
\hline & & SD & 1.1 & 1.1 & 1.1 & & \\
\hline & & SEM & 0.4 & 0.4 & 0.4 & & $\mathrm{p}<0.01^{*}$ \\
\hline & & $\mathrm{V}[\%]$ & 33 & 3.5 & 3.6 & & (1b)-(2b) \\
\hline & Lesion-free & $X$ & 31.7 & 30.7 & 29.7 & (a)-(b) $p<0.05^{*}$ & $p<0.01^{*}$ \\
\hline & skin (2) & SD & 1.2 & 1.0 & 0.8 & (a)-(c) $p<0.001^{*}$ & $(1 c)-(2 c)$ \\
\hline & & SEM & 0.4 & 0.3 & 0.3 & (b)-(c) $p<0.05^{\star}$ & \\
\hline & & $\mathrm{V}[\%]$ & 3.9 & 3.2 & 2.8 & & \\
\hline
\end{tabular}


Table 2. Evaluation of psoriatic plaques using clinical parameters (erythema, infiltration and desquamation). Ibefore treatment-1st week, II-7th day of treatment-2nd week, III-14th day of treatment-3rd week

\begin{tabular}{|c|c|c|c|c|c|c|c|c|c|c|c|c|c|c|c|c|c|}
\hline \multirow{3}{*}{$\begin{array}{l}\text { Exa- } \\
\text { mined } \\
\text { area }\end{array}$} & \multirow{3}{*}{$\begin{array}{l}\text { Date of } \\
\text { evalu- } \\
\text { ation }\end{array}$} & \multicolumn{15}{|c|}{ Measured parameter with number of measurements } & \multirow[t]{3}{*}{$P<0.05$} \\
\hline & & \multicolumn{5}{|c|}{ Erythema (a) } & \multicolumn{5}{|c|}{ Infiltration (b) } & \multicolumn{5}{|c|}{ Desquamation (c) } & \\
\hline & & 0 & 1 & 2 & 3 & 4 & 0 & 1 & 2 & 3 & 4 & 0 & 1 & 2 & 3 & 4 & \\
\hline \multirow{3}{*}{ Chest } & I & 0 & 0 & 6 & 2 & 2 & 0 & 4 & 5 & 1 & 0 & 3 & 5 & 2 & 0 & 0 & \multirow{3}{*}{$\begin{array}{l}\text { (al)-(alll) } \\
\text { (bl)-(blll) } \\
\text { (cl)-(clll) }\end{array}$} \\
\hline & II & 0 & 2 & 6 & 2 & 0 & 0 & 8 & 2 & 0 & 0 & 7 & 3 & 0 & 0 & 0 & \\
\hline & III & 0 & 8 & 2 & 0 & 0 & 4 & 6 & 0 & 0 & 0 & 10 & 0 & 0 & 0 & 0 & \\
\hline \multirow[t]{3}{*}{ Back } & I & 0 & 0 & 3 & 4 & 3 & 0 & 3 & 4 & 2 & 1 & 2 & 6 & 1 & 1 & 0 & \multirow[t]{3}{*}{ (al)-(alll) } \\
\hline & II & 0 & 1 & 6 & 3 & 0 & 0 & 3 & 4 & 3 & 0 & 7 & 3 & 0 & 0 & 0 & \\
\hline & III & 0 & 9 & 1 & 0 & 0 & 3 & 4 & 3 & 0 & 0 & 10 & 0 & 0 & 0 & 0 & \\
\hline \multirow{3}{*}{$\begin{array}{l}\text { Upper } \\
\text { limbs }\end{array}$} & I & 0 & 0 & 1 & 7 & 2 & 0 & 2 & 4 & 4 & 0 & 1 & 6 & 3 & 0 & 0 & \multirow{3}{*}{$\begin{array}{l}\text { (al)-(allI) } \\
\text { (all)-(alli) } \\
\text { (bl)-(blll) } \\
\text { (bll)-(blll) }\end{array}$} \\
\hline & II & 0 & 1 & 5 & 4 & 0 & 0 & 3 & 7 & 0 & 0 & 4 & 6 & 0 & 0 & 0 & \\
\hline & III & 0 & 7 & 3 & 0 & 0 & 2 & 8 & 0 & 0 & 0 & 10 & 0 & 0 & 0 & 0 & \\
\hline \multirow{3}{*}{$\begin{array}{l}\text { Lower } \\
\text { limbs }\end{array}$} & 1 & 0 & 0 & 2 & 7 & 1 & 0 & 0 & 0 & 7 & 3 & 0 & 1 & 6 & 0 & 3 & \multirow{3}{*}{$\begin{array}{l}\text { (al)-(all)- (alll) } \\
\text { (bl)-(bll)-(blll) }\end{array}$} \\
\hline & II & 0 & 0 & 8 & 2 & 0 & 0 & 0 & 6 & 4 & 0 & 1 & 9 & 0 & 0 & 0 & \\
\hline & III & 0 & 9 & 1 & 0 & 0 & 0 & 4 & 6 & 0 & 0 & 10 & 0 & 0 & 0 & 0 & \\
\hline
\end{tabular}

\section{DISCUSSION}

Thermographic imaging is more and more frequently used in diagnosing, disease severity evaluation, treatment planning, mainly in conditions characterized by an increased blood flow or inflammation development $[14,20,21]$. It is well documented that in the evolution of psoriatic lesions increased blood flow, hyperkerparakeratosis and inflammation are observed [3-6]. All these findings seem to influence surface body temperature measurements, which is in line with our results.

Literature data on thermography in psoriasis dates back to the seventies of the last century [25-27]. Mustakallio introduced contact thermography to study influence of dithranol staining properties on erythema estimation in psoriasis [28]. Then Warshaw and Lopez demonstrated a disturbed reaction to cold challenge in psoriatic patients [29]. Ippolito et al employed thermographic methods to study the blood flow in psoriatic patients treated with cyclosporin and observed prolongation of the thermal recovery time together with plaque clearance [30]. Maleszka et al reported that the skin lesions covered with scales seemed to be hypothermic because excessive scales (hyperkeratosis) acted as an isolation layer and only papular lesions on erythematous base demonstrated increased temperature [31]. Our results seem to confirm the above observations.

Our previous preliminary study demonstrated fairly increased skin temperature on thermography over the lesions which were in an active phase and over the clinically uninvolved skin, which later transferred into psoriatic lesions [32]. We have also observed decrease in temperature measurement as the lesions regressed [33], which is in line with presented results. We also demonstrated that thermograpy is much more sensitive in disease severity assessment than clinical evaluation alone [34, 35].

It is conceivable to speculate that severe infiltration of the skin leading to epidermal hypertrophy could cause some temperature decrease. However, further studies performed on more numerous groups, presenting a wider spectrum of diversity in clinical parameters evaluation are required to confirm the above results.

\section{CONCLUSIONS}

Thermography seems to be a more sensitive method in clinical assessment of psoriatic lesion regression than simple evaluation of erythema, infiltration and desquamation and could serve as marker of disease remission. What is more, lesion-free skin in psoriatic patients seems to be somehow involved in the pathological process in psoriasis suggesting that it is prepared for lesion progression.

\section{ACKNOWLEDGEMENTS}

This work was supported by the Medical University of Łódź Grants 502-11-726 and 503-1019-2, Statutory Grant of the Technical University of Łódź and III-6.05 CIOP-PIB research grant.

\section{REFERENCES}

[1] Bos JD, de Rie MA, Teunissen MBM, Piskin G: Psoriasis: dysregulation of innate immunity, Br J Dermatol 2005;152:1098-1107.

[2] Farber EM, Nall ML: The natural history of psoriasis in 5,600 patients. Dermatologica 1974;148:1-18.

[3] Krueger G, Ellis CN: Psoriasis - recent advances in understanding its pathogenesis and treatment. J Am Acad Dermatol 2005;53:S94-S100.

[4] Schön MP, Boehncke WH: Psoriasis. N Engl J Med, 2005;352:1899-1912. 
[5] Barton SP, Abdullah MS, Marks R: Quantification of microvascular changes in the skin in patients with psoriasis. Br J Dermatol 1992;126:569-574.

[6] Mordovstev VN, Albanova VI: Morphology of skin microvasculature in psoriasis. Am J Dermatopathol 1989;11:33-42.

[7] Speight EL, Essex TJH, Farr PM: The study of plaques of psoriasis using a scanning laser-Doppler velocimeter. Br J Dermatol 1993;128:519-524.

[8] Nyfors A, Rothenborg HW: Cutaneous blood flow in psoriasis measured by 133Xenon clearance. J Invest Dermatol 1970;54:381-385.

[9] Krogstad AL, Swanbeck G, Wallin BG: Axon-reflex-mediated vasodilatation in the psoriatic plaque. J Invest Dermatol 1995;104:872-876.

[10] Hern S, Stanton AWB, Mellor R, Levick JR, Mortimer PS: Control of cutaneous blood vessels in psoriatic plaques. J Invest Dermatol 1999;113:127-132.

[11] Klemp P, Staberg B: Cutaneous blood flow in psoriasis. J Invest Dermatol 1983;81:503-506.

[12] Braverman IM, Sibley J: Role of microcirculation in the treatment and pathogenesis of psoriasis. J Invest Dermatol 1982;78:12-17.

[13] Khan A, Schall LM, Tur E, Maibach HI, Guy RH: Blood flow in psoriatic skin lesions: the effect of treatment. Br J Dermatol 1987;117:193-201.

[14] Telner P, Fekete Z: The capillary responses in psoriatic skin. J Invest Dermatol 1961;36:225-230.

[15] De Angelis R, Bugatti L, Del Medico P, Nicolini M, Filosa G: Videocapillaroscopic findings in the microcirculation of the psoriatic plaque. Dermatology 2002;204:236-239.

[16] Jung A, Zuber J, Ring F (eds): A casebook of infrared imaging in clinical medicine., Medpress, Warszawa 2003.

[17] Ring EFJ, Ammer K: The technique of infra red imaging in medicine. Thermology International 2000;10:714.

[18] Buczylko K, Wiecek B, Chwala C: Application of thermography for evaluation of the allergen provocation. In: Quantitative Infrared Thermography 4, ed. Balageas D, Busse G, Carlomagno GM, Wiecek B, Institute of Electronics Technical University of Lodz, 1998, p 9-14.

[19] Harding JR: Thermal imaging in the investigation of deep venous thrombosis. In: Quantitative Infrared Thermography 4, ed. Balageas D, Busse G, Carlomagno GM, Wiecek B, Institute of Electronics Technical University of Lodz, 1998, p 26-28.

[20] Howell KJ, Martini G, Murray KJ, Smith RE, Black CM: Infrared thermography for the assessment of localized scleroderma in children. Thermology International 2000;10:204-209.

[21] Kapkaev RA, Kim EG, Vaisov A Sh, Skorodumov VG: Thermograpic studies in some dermatoses. (Russian) Vestn Dermatol Venereol 1977;(6):48-51.

[22] Mikulska D, Maleszka R, Rozewicka M: Application of thermographic imaging as a diagnostic technique in dermatology. Dermatol Klin 2002;4:57-60.

[23] Wiecek B, Peszynski-Drews C, Wysocki M, Jakubowska T, Danych R, Zwolenik S: Advanced methods of thermal image processing for medical and biological applications. Wiecek B (ed), Lodart S.A., Lodz, 2003, p 29-40.

[24] Kuenzli S, Saurat JH: Effect of topical PPARbeta/delta and PPARgamma agonists in plaque psoriasis. A pilot study. Dermatology 2003;206:252-256.

[25] Warshaw TG: Thermal studies in psoriasis. J Invest Dermatol 1973;60:91-93.

[26] Bogin IN, Antonev AA, Bashlikova TM, Marzeeva GI: Importance of thermography in the examination of patients with psoriatic arthropathy. Klin Med (Mosk) 1974;52:115-118.

[27] Loreck D, Lips H, Schulze D: Comparative clinical, x-ray, scintigraphic and thermographic studies in psoriasis arthropatica. Radiol Diagn (Berl) 1988;29:397-404.

[28] Mustakallio KK: Irritation and staining by dithranol (antralin) and related compounds: I. Estimation with chamber testing and contact thermography. Acta Derm Venereol (Stockh) (Suppl) 1979:59:125-132.

[29] Warshaw TG, Lopez F: Thermo-regulatory function in skin: an aspect of psoriasis. Acta Thermographica 1980;5:22-24

[30] Ippolito F, Di Carlo A, Carducci M, Leone G, Frascione P: Cyclosporin A and psoriasis: a thermographic study. Acta Derm Venereol (Stockh) (Suppl):1989;146:155-158.

[31] Maleszka R, Rozewicka M, Parafiniuk M, Kempinska A, Mikulska D: Trial of thermographic investigations application in patient with psotriatic arthritis. Dermatol Klin 2003;5:11-15.

[32] Zalewska A, Wiecek B, Zwolenik S, Lis M, Sysa-Jedrzejowska A: Evaluation of psoriasis vulgaris lesions based on thermography. Thermology International 2003;13:140-147.

[33] Zalewska A, Gralewicz G, Owczarek G, Więcek B, Sysa-Jędzrejowska A. Thermography in evaluation of chronic skin lesion regression - case report. Proceeding of the VI National Conference Thermography and Thermometry in infrared. Ustroń-Jaszowiec 4-6.11.2004, 183-187.

[34] Zalewska A, Więcek B, Sysa-Jędrzejowska A, Gralewicz G, Owczarek G. Qualitative thermographic analysis of psoriatic skin lesions. Proceedings of the 26th Annual International Conference of the IEEE EMBS, San Francisco, CA, USA, 1-5.09.2004, 1192-1195.

[35] Zalewska A, Gralewicz G, Owczarek G, Więcek B. Thermography in psoriasis vulgaris evaluation. Proceedings of the 27th Annual International Conference of the IEEE EMBS, Shanghai, China, 1-4.09.2005, $1-4$. 